\title{
PENGEMBANGAN PERANGKAT PEMBELAJARAN MATEMATIKA REALISTIK BERBANTUAN MEDIA MTB UNTUK MATERI OPERASI PENJUMLAHAN DAN PENGURANGAN BILANGAN BULAT DI KELAS IV SEKOLAH DASAR
}

\author{
Enik Chairul Umah \\ Pendidikan Dasar, Pascasarjana Universitas Negeri Surabaya
}

\begin{abstract}
Abstrak
Penelitian ini dilatarbelakangi oleh kesulitan peserta didik dalam memahami operasi penjumlahan dan pengurangan bilangan bulat. Hal ini dikarenakan peserta didik cenderung menerima apa yang disampaikan guru dalam memelajari materi baru dan jarang mengungkapkan pendapatnya. Salah satu cara untuk mengatasi kesulitan tersebut adalah dengan menerapkan pembelajaran pendidikan matematika realistik berbantuan media MTB. Penelitian ini bertujuan untuk mengembangkan perangkat pembelajaran matematika realistik berbantuan media MTB yang baik dan mendeskripsikan keefektifan pembelajaran matematika pada materi penjumlahan dan pengurangan bilangan bulat menggunakan perangkat pembelajaran matematika realistik berbantuan media MTB di kelas IV SD.

Subjek penelitian ini adalah peserta didik kelas IV SD Muhammadiyah 1 Pucang Anom Sidoarjo tahun pelajaran 2015/2016 yang terdiri dari enam kelas paralel, terpilih kelas IV Ali bin Abi Thalib untuk kelas uji coba dan kelas IV Khalid bin Walid untuk kelas implementasi. Dalam penelitian ini peneliti mengembangkan perangkat pembelajaran menggunakan model 4-D. Perangkat yang dihasilkan meliputi: RPP, media MTB, LKP, dan Lembar penilaian yang terdiri atas THB , lembar penilaian afektif dan psikomotor.

Hasil penelitian menunjukkan: (1) Perangkat pembelajaran yang dikembangkan memenuhi kriteria: (a) kevalidan, dimana penilaian validator terhadap perangkat pembelajaran adalah baik dengan skor antara 4,005,00 , (b) kepraktisan, hal ini ditunjukkan oleh kemampuan guru dalam mengelola pembelajaran berkategori baik dengan rata-rata setiap pertemuan 4,18 dan 4,27 (c) keefektifan, ditunjukkan oleh aktivitas peserta didik dalam pembelajaran berada pada rentang waktu ideal, ketuntasan klasikal hasil belajar kognitif mencapai 97,4\%, hasil belajar afektif $89,7 \%$, dan hasil belajar psikomotor 97,44\%, dan respon peserta didik positif (2) pembelajaran menggunakan perangkat pembelajaran matematika realistik berbantuan media MTB efektif untuk mengajarkan materi penjumlahan dan pengurangan bilangan bulat. Hal ini ditunjukkan oleh: (a) ketuntasan hasil belajar klasikal pada kelas implementasi untuk hasil belajar kognitif mencapai 87,09\%, hasil belajar afektif mencapai $87,10 \%$, dan hasil belajar psikomotor mencapai 80,65\%, (b) aktivitas peserta didik dalam pembelajaran berada pada rentang waktu ideal, (c) respon peserta didik terhadap pembelajaran positif. Dengan demikian, perangkat pembelajaran yang dikembangkan dapat digunakan sebagai alternatif pembelajaran pada materi operasi penjumlahan dan pengurangan bilangan bulat.
\end{abstract}

Kata-kata kunci: matematika realistik, media MTB, bilangan bulat.

\begin{abstract}
This study was conducted based on the students' difficulties in understanding the operation of addition and subtraction of integers. These students' difficulties occurred because when learning a new material, students tended to accept all the materials from the teacher instead of saying their opinion. One way to solve this problem is by implementing Realistic Mathematics Education with MTB media. The study was aimed to develop good learning instruments by utilizing Realistic Mathematics Education learning with MTB media and to describe the effectiveness of mathematics learning in the topic of addition and subtraction of integers by implementing Realistic Mathematics Education with MTB media on $4^{\text {th }}$ grade students.

The subject of the study was the $4^{\text {th }}$ grade students of SD Muhammadiyah 1 Pucang Anom Sidoarjo in academic year 2015/2016 consisting of six parallel classes, and the Ali bin Abi Thalib class of $4^{\text {th }}$ grade was selected to be the experimental class while the Khalid bin Walid class of $4^{\text {th }}$ grade was selected to be the implementation class. In this study, the researcher developed the learning instruments by using the 4-D model. The learning instruments' outcome included: RPP, MTB media, LKP, and assessment sheet that consist of THB, attitude and skill assessment.

The result of the study showed that: (1) the learning instruments developed satisfied the following criteria: (a) validity, the assessment by the validator toward the learning instruments showed the good grades and satisfied the interval $4.00-5.00$ score, (b) practicability, this was indicated by the teacher's capability in managing the learning process which was categorized good and reached the average of score 4.18 and 4.27 for each meeting, (c) effectiveness, it was indicated by the students' activities in learning process satisfied the ideal time interval, the thoroughness of cognitive classical achievement reached $97.4 \%$, the attitude achievement reached $89.7 \%$, the skill achievement reached 97.44\%, while the students' response was categorized good, (2) Realistic Mathematics
\end{abstract}


Education with MTB media was effective to teach the addition and subtraction of integers. It was indicated by: (a) the thoroughness of classical achievement on the implementation class for the cognitive achievement reached $87.09 \%$, the attitude achievement reached $87.1 \%$, while the skill achievement reached $80.65 \%$, (b) the students' activities in the learning process satisfied the interval of ideal time, and (c) the students' responses were categorized positive. Thus, the learning instruments developed can be used as an alternative way of teaching the operation of addition and subtraction of integers.

Keywords: realistic mathematics education, MTB media, integers.

\section{PENDAHULUAN}

Materi bilangan bulat adalah salah satu materi yang diajarkan di kelas VI dan ternyata peserta didik masih mengalami kesulitan saat menjumlahkan dan mengurangkan bilangan bulat. Padahal materi tersebut sudah dipelajari di kelas IV. Saat didiskusikan dengan guru kelas IV diperoleh informasi bahwa penguasaan peserta didik pada materi bilangan bulat kurang maksimal. Hal ini sesuai dengan pernyataan peserta didik saat tanya jawab, bahwa mereka masih bingung ketika menjumpai tanda operasi penjumlahan dan pengurangan dengan bilangan negatif. Secara umum peserta didik juga menyatakan bahwa matematika merupakan mata pelajaran yang sulit dipelajari.

Bilangan yang dipelajari oleh peserta didik di jenjang Sekolah Dasar dalam Standart Isi meliputi bilangan cacah, bilangan asli, bilangan prima, dan bilangan bulat. Bilangan bulat menurut Bennet dan Nelson (2004:251) adalah gabungan bilangan cacah dan bilangan negatifnya. Sementara Musser dan Burger (2013:283) menyatakan bahwa "Integer's is the set of numbers that consist of the whole numbers, together with the negative numbers that are the opposites of the non zero whole number". Berdasar kutipan tersebut yang dimaksud dengan bilangan bulat adalah himpunan bilangan yang terdiri atas bilangan cacah bersama dengan bilangan negatif yang merupakan lawan dari bilangan cacah selain nol.

Bilangan negatif merupakan materi baru dan bersifat abstrak bagi peserta didik di Kelas IV sehingga sulit dipahami oleh peserta didik. Kesulitan yang dialami peserta didik terjadi pada saat mengoperasikan bilangan negatif, hal ini disebabkan karena peserta didik belum memahami perbedaan fungsi tanda (-), yakni sebagai tanda operasi pengurangan (-) dalam konteks operasi penjumlahan $(+)$ dan pengurangan $(-)$ maupun sebagai tanda negatif (-) dalam konteks sebagai tanda positif dan negatif dari bilangan. Sebagaimana disampaikan Walle (2006:240), sampai peserta didik menjumpai bilangan bulat, tanda positif dan negatif hanya digunakan untuk operasi penjumlahan dan pengurangan. Notasi bilangan bertanda menjadi permasalahan bagi banyak peserta didik. Dengan demikian penggunaan model menjadi hal penting bagi peserta didik dalam memahami operasi penjumlahan maupun pengurangan bilangan bulat, karena perkembangan kognitif peserta didik berada pada level operasi konkret.

Di sisi lain, permasalahan bagi banyak peserta didik dalam belajar matematika disebabkan dari obyek yang dikaji. Soedjadi (2000:13) menyatakan bahwa, dalam matematika objek dasar yang dipelajari adalah abstrak, sering juga disebut objek mental. Ini berarti yang dibahas dalam pembelajaran matematika bukanlah obyek-obyek konkret, atau obyek yang bisa dilihat langsung, dipegang, diraba, atau ditangkap oleh panca indera lainnya.

Sifat abstraknya obyek kajian matematika menimbulkan masalah sulitnya peserta didik menangkap ide-ide matematika. Di sinilah peran guru sebagai pengajar harus mampu memberikan fasilitas belajar seperti buku teks dan alat bantu belajar yang baik sehingga peserta didik dapat memahami materi yang bersifat abstrak dengan baik. Guru sebagai tenaga pengajar di kelas hendaknya berusaha sedapat mungkin untuk membangkitkan minat belajar para peserta didik dengan berbagai cara. Cara yang dapat ditempuh misalnya dengan memberikan masalah-masalah nyata yang dekat dengan kehidupan peserta didik atau penggunaan media yang menarik dalam pembelajaran. Dalam proses pembelajaran matematika, pendekatan konkret perlu disajikan terlebih dahulu sehingga pengalaman konkret itu dapat menjadi jembatan untuk memelajari yang abstrak.

Berdasarkan hal-hal tersebut dapat disimpulkan bahwa dalam belajar matematika, pengalaman belajar matematika sangat penting. Pengalaman tersebut akan membentuk pemahaman apabila ditunjang dengan pembelajaran melalui dunia nyata atau dengan mempresentasikan materi melalui benda-benda nyata. Salah satu pendekatan pembelajaran matematika yang dapat digunakan untuk menciptakan pembelajaran yang bermakna, mengaktifkan dan menyenangkan adalah 
pembelajaran menggunakan pendidikan matematika realistik dengan berbantuan media.

Terdapat dua media populer untuk membantu peserta didik memahami operasi hitung pada bilangan bulat. Dua media tersebut adalah media yang menggunakan model Dua Pencacah dan model Garis Bilangan (Walle, 2006:240). Model Dua Pencacah adalah model yang terdiri atas pencacah dengan dua warna yang berbeda. Satu warna untuk positif dan warna lain untuk negatif. Dua warna tersebut saling berlawanan (membuat nol) (Walle, 2006:240). Pada model Dua Pencacah, satu pencacah mewakili satu satuan, model ini akan efektif digunakan untuk operasi hitung pada bilangan yang kecil, namun bila bilangannya besar misalnya puluhan atau ratusan maka peserta didik memerlukan waktu yang cukup lama untuk mencacah, maka untuk menghemat waktu dan mempermudah mencacah perlu memodifikasi model Dua Pencacah ini.

Media Mencari Teman Bilangan (MTB) merupakan modifikasi dari model Dua Pencacah, berupa pencacah yang terdiri atas dua warna yang berbeda, saling berlawanan, dan terdiri atas tiga bentuk yaitu bentuk lingkaran mewakili nilai ratusan, persegi mewakili nilai puluhan, dan segitiga mewakili nilai satuan. Diharapkan dengan pemodifikasian ini dapat memudahkan dan menghemat waktu dalam mencacah. Untuk mengimplementasikan pembelajaran dengan media Mencari Teman Bilangan (MTB) tersebut, perlu dikembangkan perangkat pembelajaran. Perlunya dikembangkan perangkat pembelajaran didasari oleh (1) hasil evaluasi pembelajaran tahun-tahun sebelumnya dan informasi dari guru kelas IV pada forum KKG gugus 02 kecamatan Sidoarjo yang menyatakan bahwa secara umum peserta didik kelas IV mengalami kesulitan dalam memahami operasi hitung penjumlahan dan pengurangan bilangan bulat, sedangkan pembelajaran yang dilakukan guru masih bersifat mekanistik dan memperbanyak drill/latihan-latihan, (2) belum adanya perangkat pembelajaran yang memadai yang memberikan kemudahan guru dalam melaksanakan pembelajaran yang tepat yang mempertimbangkan perkembangan kognitif dan kemampuan peserta didik.

Berdasarkan uraian latar belakang tersebut, maka rumusan masalah dalam penelitian ini adalah: (1) Bagaimanakah hasil pengembangan perangkat pembelajaran matematika realistik berbantuan media MTB untuk materi operasi penjumlahan dan pengurangan bilangan bulat di Kelas IV Sekolah Dasar?, (2) Bagaimanakah keefektifan pembelajaran matematika pada materi penjumlahan dan pengurangan bilangan bulat menggunakan perangkat pembelajaran matematika realistik berbantuan media MTB di Kelas IV Sekolah Dasar?. Sesuai dengan rumusan masalah tersebut maka tujuan penelitian ini adalah: (1) Menghasilkan perangkat pembelajaran matematika realistik berbantuan media MTB yang mendukung pembelajaran operasi penjumlahan dan pengurangan bilangan bulat di Kelas IV Sekolah Dasar. (2) Mendiskripsikan keefektifan pembelajaran pada materi penjumlahan dan pengurangan bilangan bulat menggunakan perangkat pembelajaran matematika realistik berbantuan media MTB di Kelas IV Sekolah Dasar.

\section{TINJAUAN PUSTAKA}

Pendidikan Matematika Realistik (PMR) merupakan suatu pendekatan pembelajaran matematika yang telah dikembangkan di Belanda dengan nama Realistic Mathematics Education. Van den Hauvel-Panhuizen (dalam Wijaya, 2011:20) menyatakan bahwa penggunaan kata "realistik" sebenarnya berasal dari bahasa Belanda "zich realiseren" yang berarti untuk dibayangkan atau "to imagine". Masih menurut Van den HauvelPanhuizen, penggunaan kata "realistik" tersebut tidak sekedar menunjukkan adanya suatu koneksi dengan dunia nyata (real world) tetapi lebih mengacu pada fokus Pendidikan Matematika Realistik dalam menempatkan penekanan penggunaan suatu situasi yang bisa dibayangkan (imagineable) oleh peserta didik.

PMR pada dasarnya adalah pemanfaatan realitas dan lingkungan yang

dipahami peserta didik untuk keberhasilan pembelajaran matematika sehingga mencapai tujuan pendidikan matematika secara lebih baik. Treffers (1978:248) merumuskan lima karakteristik PMR, yaitu: penggunaan konteks, pengunaan model, Pemanfaatan hasil konstruksi peserta didik, Interaktivitas, dan keterkaitan. Langkah-langkah Pendidikan Matematika Realistik menurut Sumaryanta (2013:2) ada empat yaitu: memberikan masalah kontekstual, menyelesaikan masalah kontekstual, membandingkan dan mendiskusikan jawaban, dan menarik simpulan.

Bilangan Bulat adalah bilangan cacah beserta negatifnya atau lawannya (Walle, 2006:239). Menurut Bennett (2004:251), bilangan bulat adalah bilangan cacah beserta bilangan negatifnya. Sedangkan Karso (2012:3.4) menyatakan, bilangan bulat adalah penggabungan dari bilangan-bilangan cacah dan bilangan-bilangan asli yang negatif. Definisi yang dinyatakan oleh Billstein (1990: 193) bahwa: "If $n$ is integer, then the unique integer ${ }^{-} n$ is called the opposite of $n$ if $n$ $+\left({ }^{-} n\right)=0=\left({ }^{-} n\right)+n$. Artinya jika $\mathrm{n}$ adalah 
bilangan bulat, maka bilangan bulat $\quad(-n)$ dinamakan lawan dari $n$ jika $n+(-n)=0=(-n)+n$. Berdasar uraian tersebut dapat disimpulkan bahwa operasi penjumlahan

dan pengurangan bilangan bulat adalah proses, cara atau pengerjaan menjumlahkan dan mengurangkan bilangan cacah beserta bilangan negatifnya.

Media Mencari Teman Bilangan merupakan modifikasi dari model Dua Pencacah. Pada model Dua Pencacah setiap pencacah mewakili nilai satuan, sedangkan pada media MTB pencacah mewakili puluhan dan satuan. Media MTB adalah media berupa pencacah yang terbuat dari bahan rubber spon. Pencacah terdiri dari dua bentuk yaitu persegi dan segitiga. Pencacah berbentuk persegi mewakili nilai puluhan dan bentuk segi tiga mewakili nilai satuan. Pencacah terdiri atas dua warna yang saling berlawanan (pembuat nol), warna kuning menunjukkan positif (+) dan warna merah menunjukkan negatif (-).

Berdasar tahap perkembangan kognitif Piaget, taraf berfikir peserta didik kelas IV Sekolah Dasar berada pada tahap operasional konkret, artinya untuk memahami suatu konsep masih harus diberikan kegiatan yang berhubungan dengan benda nyata atau kejadian nyata yang dapat diterima akal mereka. Penggunaan media MTB sebagai sarana penyediaan benda nyata dalam pembelajaran sebagai jembatan peserta didik dapat membantu menurunkan keabtrakan konsep yang diajarkan.

Pembelajaran dengan media Mencari Teman Bilangan (MTB), dimana peserta didik mendapatkan stimulasi berupa manipulasi benda konkret sejalan dengan Teori Thorndike. Pembelajaran dengan media Mencari Teman Bilangan dalam aspek penyediaan media sejalan dengan Teori Vigotsky. Pembelajaran dengan media Mencari Teman Bilangan (MTB) dalam aspek visualisasi bilangan bulat dalam bentuk benda konkret sejalan dengan Teori Paivio.

\section{METODE}

Jenis penelitian yang dilakukan adalah jenis penelitian pengembangan, sebab penelitian bertujuan untuk mengembangkan dan menghasilkan sebuah perangkat pembelajaran matematika dengan menggunakan media Mencari Teman Bilangan (MTB) yang berkualitas baik. Bagian perangkat yang dikembangkan dalam penelitian ini adalah perangkat pembelajaran yang meliputi: Rencana Pelaksanaan Pembelajaran (RPP), media Mencari Teman Bilangan (MTB), Lembar Kegiatan Peserta didik (LKP), dan Tes Hasil Belajar (THB).

Model pengembangan yang digunakan sebagai acuan adalah model pengembangan 4-D dari Thiangarajan, Semmel dan Semmel (1974:5).
Penelitian akan dilaksanakan di SD Muhammadiyah 1 Pucang Anom Sidoarjo. Banyak peserta didik kelas IV di SD Muhammadiyah 1 Pucang Anom Sidoarjo tahun ajaran 2015/2016 sebanyak 197 peserta didik yang terbagi dalam lima kelas, yaitu 40 peserta didik masing-masing di kelas IV Abu Bakar dan kelas IV Umar, sedangkan tiga kelas masing-masing terdiri dari 39 peserta didik, yaitu IV Ustman, kelas IV Ali dan IV Khalid.Subjek penelitian adalah kelas IV Ali dan kelas IV Khalid SD Muhammadiyah 1 Sidoarjo, dimana kelas IV Ali digunakan sebagai kelas uji coba, sedangkan kelas IV Khalid digunakan sebagai kelas implementasi. Pemilihan kelas ditentukan berdasarkan persetujuan dengan waka kurikulum.

\section{HASIL PENELITIAN}

Hasil penelitian menunjukkan: (1) Perangkat pembelajaran yang dikembangkan memenuhi kriteria: (a) kevalidan, dimana penilaian validator terhadap perangkat pembelajaran adalah baik dengan skor antara 4,00-5,00, (b) kepraktisan, hal ini ditunjukkan oleh kemampuan guru dalam mengelola pembelajaran berkategori baik dengan rata-rata setiap pertemuan 4,18 dan 4,27 (c) keefektifan, ditunjukkan oleh aktivitas peserta didik dalam pembelajaran berada pada rentang waktu ideal, ketuntasan klasikal hasil belajar kognitif mencapai $97,4 \%$, hasil belajar afektif $89,7 \%$, dan hasil belajar psikomotor 97,44\%, dan respon peserta didik positif (2) pembelajaran menggunakan perangkat pembelajaran matematika realistik berbantuan media MTB efektif untuk mengajarkan materi penjumlahan dan pengurangan bilangan bulat. Hal ini ditunjukkan oleh: (a) ketuntasan hasil belajar klasikal pada kelas implementasi untuk hasil belajar kognitif mencapai $87,09 \%$, hasil belajar afektif mencapai $87,10 \%$, dan hasil belajar psikomotor mencapai $80,65 \%$, (b) aktivitas peserta didik dalam pembelajaran berada pada rentang waktu ideal, (c) respon peserta didik terhadap pembelajaran positif. Dengan demikian, perangkat pembelajaran yang dikembangkan dapat digunakan sebagai alternatif pembelajaran pada materi operasi penjumlahan dan pengurangan bilangan bulat.

\section{SIMPULAN dan SARAN}

Berdasarkan analisis data dan diskusi hasil penelitian, diperoleh kesimpulan berikut:

1. Penelitian pengembangan ini menghasilkan perangkat pembelajaran matematika realistik berbantuan media MTB yang terdiri atas Rencana Pelaksanaan Pembelajaran (RPP), Media MTB, Lembar Kegiatan Peserta didik 
(LKP), dan Lembar penilaian (THB, lembar penialain afektif, dan psikomotor).

2. Perangkat pembelajaran yang dikembangkan memenuhi kriteria perangkat yang baik setelah melalui tahap validasi dan uji coba lapangan. Hal ini dapat dilihat dari tercapainya kriteria perangkat yang baik, yaitu:

a. Penilaian validator terhadap perangkat pembelajaran dalam kategori baik.

b. Kemampuan guru mengelola pembelajaraan dalam kategori baik, hal ini menunjukkan bahwa guru mitra mampu mengelola pembelajaran dengan baik.

c. Aktivitas peserta didik memenuhi kategori baik.

d. Hasil belajar peserta didik memenuhi kriteria ketuntasan.

e. Tes hasil belajar memenuhi kriteria valid, reliabel, dan sensitif.

f. Respon peserta didik terhadap perangkat pembelajaran positif.

3. Pembelajaran matematika realistik berbantuan media MTB efektif untuk materi operasi penjumlahan dan pengurangan pada bilangan bulat. Hal ini dapat dilihat dari:

a. Hasil belajar peserta didik secara klasikal tercapai, hal ini terlihat dari hasil belajar kognitif peserta didik $87,09 \%$ mencapai nilai $\geq 75$, hasil belajar afektif $87,1 \%$ mencapai kriteria baik, dan hasil belajar psikomotor $80,65 \%$ mencapai kriteria baik.

b. Aktivitas peserta didik memenuhi kriteria baik.

c. Respon peserta didik terhadap pembelajaran positif.

Berdasarkan hasil penelitian dan pengalaman selama melakukan penelitian, peneliti memberikan saran sebagai berikut.

1. Pengembangan perangkat pembelajaran matematika realistik berbantuan media MTB dapat digunakan sebagai alternatif pembelajaran pada materi operasi penjumlahan dan pengurangan bilangan bulat.

2. Hendaknya peneliti lain menindaklanjuti penelitian ini untuk menyempurnakan atau setidaknya mengurangi kelemahan-kelemahan dalam penelitian ini, agar diperoleh hasil penelitian yang lebih akurat.

\section{DAFTAR PUSTAKA}

Akbar, Sa'dun. (2013). Instrumen Perangkat Pembelajaran. Bandung: PT. Remaja Rosdakarya.
Akker, Van Den. (1999). "Principles and Methods of Development Research". University of Twente, the Nederlands.

Armstrong, Thomas. (2002). Setiap Anak Cerdas. Jakarta: PT. Gramedia Pustaka Utama

Arends, Richard I. (2013). Belajar untuk Mengajar Learning to Teach. Jakarta: Salemba Humanika

Arikuto, Suharsimi. (2006). Prosedur Penelitian Suatu Pendekatan Praktek. Jakarta: Rieka Cipta

Arsyad, Azhar. (2002). Media Pembelajaran. Edisi 1. Jakarta: PT. Raja Grafindo Persada

Azwar, Saifuddin. (2007). Tes Prestasi. Fungsi dan Pengembangan Pengukuran

Prestasi Belajar. Edisi ke-2. Yogyakarta: Pustaka Pelajar

Bennett, Albert B. (2004). Mathematics For Elementary Teachers A Conceptual Approach. United States: Von Hoffmann Corporation.

Billstein, R., Libeskind, S., Lott, JW., (1990). A Problem Solving Approach to Mathematics for Elementary School teachers. California: The Benjamin/Cummings Publishing Company, Inc

BSNP. (2006). Standar Nasional Pendidikan Indonesia untuk Satuan Pendidikan Dasar dan Menengah. Jakarta: Ditjendikdasmen

Daryanto. (2013). Inovasi Pembelajaran Efektif. Bandung: Yrama Widya

Day, R., Frey, P., Howard, A.C., Hutchens, D.A., Luchin, B. (2008). California Mathematics Concepts, Skill, And Problem Solving 7. United States: The McGraw-Hill Companies, Inc.

Depdiknas. (2003). Undang-undang Sistem Pendidikan Nasional. Jakarta: Departemen Pendidikan Nasional.

Depdiknas. (2006). Model Kurikulum Tingkat Satuan Pendidikan. Jakarta: Badan Standart Nasional Pendidikan, 
Departemen Pendidikan Nasional.

Dirjen Pendidikan Dasar. (2014). Lampiran Permendikbud Nomor 103. Jakarta: Kementerian Pendidikan dan Kebudayaan

Dirjen Pendidikan Dasar. (2014). Panduan Teknis Penilaian dan Pengisian Raport di SD. Jakarta: Kementerian Pendidikan dan Kebudayaan

Fajar, Safrudin. (2004). Pengembangan Perangkat Pembelajaran Matematika Realistik untuk Pokok Bahasan Relasi, Pemetaan, dan Grafik Kelas II SLTP Negeri 5 Barabai Kalimantan Selatan. Surabaya: Tesis tidak dipublikasikan

Fathani. (2009). Matematika Hakikat \& Logika. Jakarta:Ar-Ruaa Media.

Grounlund, Norman E. (1982). Contructing Achievement Test. Third Edition. Engglewood Cliffs: Prentice Hall.

Hudojo, H. (1988). Mengajar Belajar Matematika. Jakarta: Dirjen Dikti

Hobri. (2010). Metodologi Penelitian Pengembangan. Aplikasi pada Penelitian Pendidikan Matematika. Jember: Pena Salsabila.

Ibrahim, Muslimin. (2003). Pembelajaran Kooperatif. Surabaya: Unesa University Press.

Ibrahim, Muslimin. (2005). Asesmen Berkelanjutan. Surabaya: Unesa University Press.

Ibrahim, Muslimin dkk. (2010). Dasar-dasar Proses Belajar Mengajar. Surabaya: Unesa University Press

Karso, dkk. (2012). Pendidikan Matematika 1. Tangerang: Universitas Terbuka.

Kemp, Jerrod E. (1994). Proses Perancangan Pengajaran. Bandung: ITB Bandung

Khabibah, Siti. (2006). Pengembangan Model Pembelajaran Matematika dengan Soal Terbuka untuk Meningkatkan Kreativitas Peserta Didik Sekolah Dasar. Surabaya: Disertasi tidak dipublikasikan.
Lampiran Permendikbud Nomor 103 Tahun 2014 Tentang Pembelajaran Pada Pendidikan Dasar Dan Pendidikan Menengah.

Lampiran Permendikbud Nomor 104 Tahun 2014 Tentang Pedoman Penilaian Hasil Belajar Oleh Pendidik.

Mahsunah, dkk. (2012). Materi Pendidikan dan Pelatihan Profesi Guru (PLPG). Jakarta: Kemendikbud.

Mudhofir. (1990). Teknologi Intruksional. Bandung: Remaja Rosdakarya

Munadi, Yudhi. (2012). Media Pembelajaran Sebuah Pendekatan Baru. Jakarta: Gaung Persada.

Musser, Gary L and Burger, William F. (1991). Mathematics for Elementary Teachers a Contemporary Approach. New York: Macmillan Publishing Company

Nieveen. (1999). "Prototyping to Reach Product Quality”. University of Twente, The Netherlands.

Nur, Mohamad. (2008). Pengajaran Berpusat kepada Siswa dan Pendekatan Kontruktifis dalam Pengajaran. Surabaya:PSMS Unesa.

Nur, Mohamad. (2008). Teori-Teori Pembelajaran Kognitif. Surabaya:PSMS Unesa.

Prastowo, Andi. (2013). Pengembangan Bahan Ajar Tematik. Jogjakarta: Diva Press.

Pribadi, Benny. (2011). Model Desain Sistem Pembelajaran. Jakarta: Dian Rakyat.

Rey's . Robery E. (1992). Helping Children Learn Mathematics. America: Simon and Schuster Inc

Sadiman, Aris S. (2011). Media Pendidikan. Jakarta: Rajawali Pers.

Salim, Yenny. (2002). Kamus Bahasa Indonesia Kontemporer. Jakarta: Modern English Press 
Sanjaya, Wina. (2006). Strategi Pembelajaran Berorientasi Standar Proses Pendidikan. Jakarta: Prenada Media Grup

Slavin, Robert E. (1994). Educational Psychology Teory Into Practices. $4^{\text {th }} \mathrm{ed}$. Boston: Ally and Bacon Publishers.

Slavin, Robert E. (2011). Psikologi Pendidikan Teori dan Praktik. Jakarta: Indeks.

Santyasa, I Wayan. (2007). Landasan Konseptual Media Pembelajaran. Makalah disajikan dalam Workshop Media Pembelajaran Bagi Guru-guru SMA Negeri Banjar Angkan Klungkung, 10 Januari 2007.

Soedjadi, R. (2000). Kiat Pendidikan Matematika di Indonesia. Jakarta: Dirjen Dikti Depdknas.

Spitzer, Dean. (1999). “Learning Effectiveness Measurement (LEM)". Dalam http://www.slidesshare.net/AllisonCristia en/em .whitepaper. 14 Mei.

Sudjana, Nana. (2011). Media Pembelajaran. Bandung: Sinar Baru.

Sudjana, Nana. (2014). Penilaian Hasil Proses Belajar Mengajar. Bandung: Remaja Rosdakarya.

Sulhan, Najib. (2006). Pembangunan Karakter Pada Anak Manajemen Pembelajaran Guru Menuju Sekolah Efektif. Surabaya: Intelektual Club.

Treffers, Adrian. (1978). Three Dimensions A Model of Goal and Theory Description in Mathematics Intruction-The Wiskobas Project. Dordrecht: Reidel Publishing Company.

Thiagarajan, S., Semmel. (1974). Instructional Development for Training Teachers of Exceptional Children. A sourcebook. Bloomington: Center for Innovatio in Theaching the Handicapped.

Triyana, Winiati Illah. (2011). Keefektifan Kooperatif Tipe TGT (Team Game Tournament) pada Aritmatika Sosial di Kelas VII SMP Zainuddin. Tesis Magister Pendidikan. Surabaya: PPs. Unesa
Trianto. (2010). Pengembangan Model Pembelajaran Tematik. Jakarta: Prestasi Pustakaraya.

Trianto. (2010). Mendesain Model pembelajaran Inovatif-Progresif. Jakarta: Kencana.

Sumaryanta. (2013). Pembelajaran Matematika Realistik dan Strategi Implementasinya di Kelas. Dalam http://p4tkmatematika.org/2013/12/pemb elajaran-matematika-realistik-danstrategi-implementasinya-di-kelas-2/. 23 Juni.

Walle, Jhon A Van De. (2006). Matematika Sekolah dasar dan Menengah. Pengembangan Pengajaran. Jilid 2, edisi keenam. Jakarta: Erlangga.

Wijaya, Ariyadi. (2012). Pendidikan Matematika Realistik Suatu Alternatif Pendekatan Pembelajaran Matematka. Yogyakarta: Graha Ilmu. 